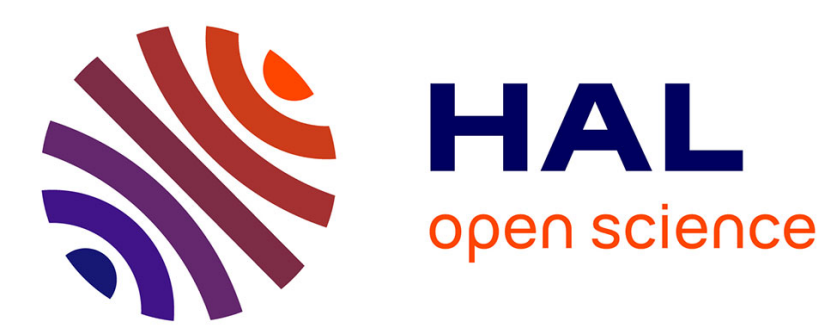

\title{
Dilemmas for regional development in the concepts seeking to develop Poland's spatial structure \\ Jerzy Banski
}

\section{To cite this version:}

Jerzy Banski. Dilemmas for regional development in the concepts seeking to develop Poland's spatial structure. Regional Studies, 2010, 44 (05), pp.535-549. 10.1080/00343400902926375 . hal-00596610

\section{HAL Id: hal-00596610 https://hal.science/hal-00596610}

Submitted on 28 May 2011

HAL is a multi-disciplinary open access archive for the deposit and dissemination of scientific research documents, whether they are published or not. The documents may come from teaching and research institutions in France or abroad, or from public or private research centers.
L'archive ouverte pluridisciplinaire HAL, est destinée au dépôt et à la diffusion de documents scientifiques de niveau recherche, publiés ou non, émanant des établissements d'enseignement et de recherche français ou étrangers, des laboratoires publics ou privés. 


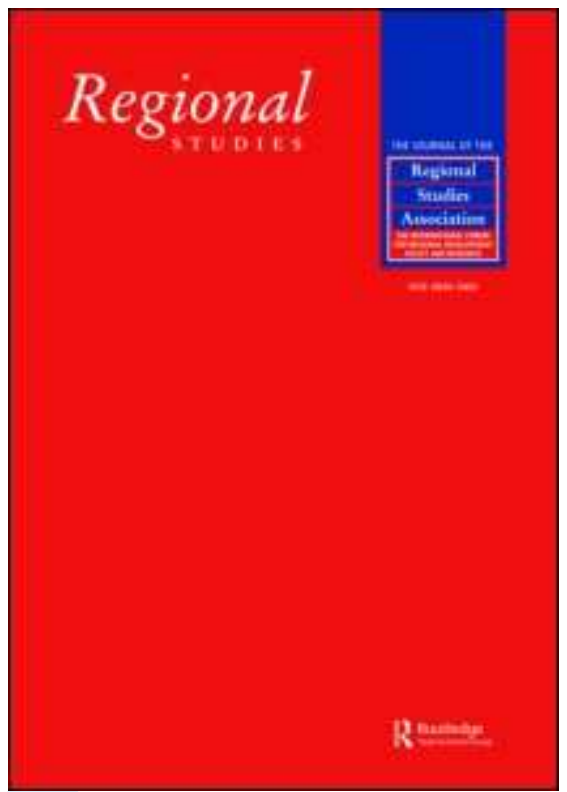

\section{Dilemmas for regional development in the concepts seeking to develop Poland's spatial structure}

\begin{tabular}{|c|l|}
\hline Journal: & Regional Studies \\
\hline Manuscript ID: & CRES-2007-0259.R3 \\
\hline Manuscript Type: & Main Section \\
\hline JEL codes: & $\begin{array}{l}\text { O1 - Economic Development < O - Economic Development, } \\
\text { Technological Change, and Growth, O18 - Regional, Urban, and } \\
\text { Rural Analyses < O1 - Economic Development < O - Economic } \\
\text { Development, Technological Change, and Growth, O21 - Planning } \\
\text { O - Economic Development, Technological Change, and Growth, R1 } \\
\text { - General Regional Economics < R - Urban, Rural, and Regional } \\
\text { Economics }\end{array}$ \\
\hline Keywords: & \begin{tabular}{l} 
spatial planning, Poland, phisical development, spatial structure \\
\hline
\end{tabular} \\
\hline
\end{tabular}

\section{S ScholaroNE \\ Manuscript Central}




\section{Dilemmas for regional development in the concepts seeking to develop Poland's spatial} structure

Professor Jerzy Bański

Institute of Geography and Spatial Organization

Polish Academy of Sciences

00-818 Warsaw, Twarda str. 51/55, Poland

jbanski@twarda.pan.pl

Received September 2007; in revised form February 2008, May 2008; accepted August 2008 


\begin{abstract}
:
Post-War Poland has seen work done on three spatial development concepts. The first - from the late 1940s - had as its task the decentralisation of industry and the strengthening of regions whose development had been lagging behind. The second - drawn up in the 1970s promoted the system of moderate polycentric concentration and a shifting of part of the country's industrial potential to more weakly-developed areas. In turn, the third concept from the 1990s - again concentrated on balancing regional development, albeit through the idea of priority being assigned to efficiency over equality. The aim of the present article has been to analyse the aforesaid three concepts as regards the approach taken to the evening out of regional development. The primary thesis here is that the concepts studied strived in their various different ways to reduce regional disparities, but never actually had the ideas they came up with put into effect properly.
\end{abstract}

Key words: Poland, spatial planning, physical development, spatial structure.

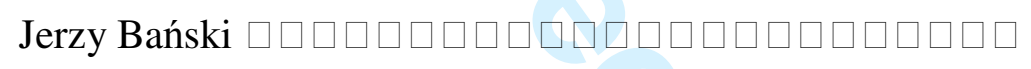

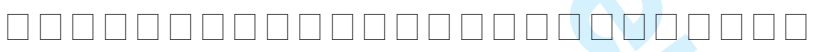

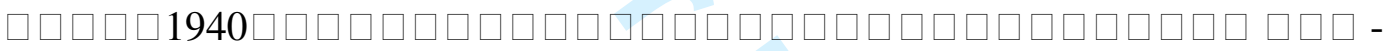

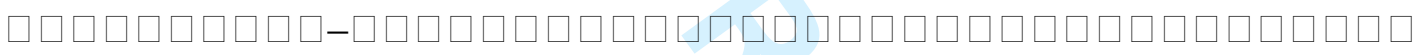

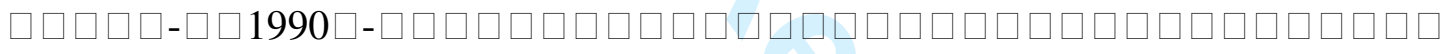

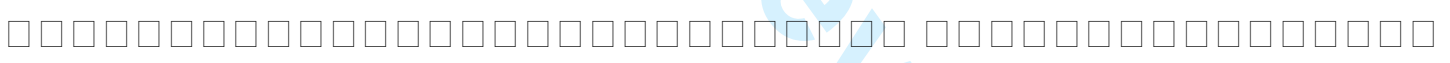

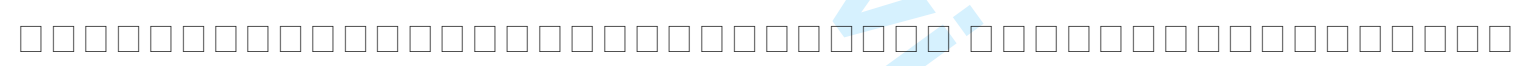

$\square \square, \square \square \square \square, \square \square \square \square, \square \square \square \square$

L'aménagement du territoire confronté à un dilemme

à propos du développement de la structure spatiale polonaise.

\title{
Bánski
}

La Pologne d'après-guerre a témoigné du développement de trois concepts d'aménagement du territoire. Le premier - qui date de la fin des années 1940 - a porté sur la décentralisation de l'industrie et le renforcement des régions en perte de vitesse. Le deuxième - qui a été développé aux années 1970 - a prôné un maillage polycentrique limité et un déplacement d'une part du potentiel industriel du pays à destination des zones défavorisées. Egalement, le troisième concept - qui date des années 1990 - a porté sur la notion d'équilibre régional, bien que ce soit à partir de l'idée que l'efficacité l'emporte sur l'égalité. Cet article cherche à analyser les trois concepts susmentionnés à l'égard de la façon d'aborder le rééquilibrage. La principale thèse est la suivante: les concepts étudiés ont cherché d'une manière ou d'une autre 
Dilemmas für die Regionalentwicklung bei den Konzepten zur Entwicklung der Raumstruktur Polens

Jerzy Bański

Abstract:

Im Polen wurde in der Nachkriegszeit an drei räumlichen Entwicklungskonzepten gearbeitet. Das erste entstand gegen Ende der vierziger Jahre und hatte sich die Dezentralisierung der Industrie sowie die Stärkung der in ihrer Entwicklung zurückgebliebenen Regionen zur Aufgabe gemacht. Das zweite aus den siebziger Jahren förderte das System einer gemäßigten polyzentrischen Konzentration und eine Verlagerung eines Teils des industriellen Potenzials des Landes in schwächer entwickelte Gebiete. Das dritte Konzept aus den neunziger Jahren wiederum konzentrierte sich erneut auf eine ausgewogene Regionalentwicklung, allerdings über die Idee, der Effizienz eine höhere Priorität einzuräumen als der Gleichheit. In diesem Artikel analysieren wir diese drei Konzepte hinsichtlich ihrer Ansätze zur gleichmäßigeren Gestaltung der Regionalentwicklung. Die primäre These hierbei lautet, das mit jedem der untersuchten Konzepte auf eigene Weise versucht wurde, die regionalen Disparitäten zu verringern; allerdings wurde keine der hierbei entwickelten Ideen jemals tatsächlich richtig umgesetzt.

Key words:

Polen, Raumplanung, Physische Entwicklung, Raumstruktur

Dilemas del desarrollo regional en cuanto a conceptos para desarrollar la estructura espacial de Polonia

Jerzy Bański

\section{Abstract:}

La posguerra de Polonia se ha caracterizado por un trabajo realizado en torno a tres conceptos de desarrollo espacial. El primero, que tuvo lugar desde finales de la década de los cuarenta, fue la tarea de descentralizar la industria y el fortalecimiento de las regiones cuyo desarrollo había quedado rezagado. El segundo, redactado en los setenta, fomentó el sistema de concentración policéntrica moderada y el traslado de una parte del potencial industrial del país a zonas menos desarrolladas. Y el tercer concepto, desarrollado a partir de los noventa, se centró de nuevo en equilibrar el desarrollo regional, aunque mediante la idea de dar prioridad a la eficacia en detrimento de la igualdad. El objetivo del presente artículo ha sido analizar estos tres conceptos mencionados con respecto al enfoque para igualar el desarrollo regional. La tesis principal aquí radica en que los conceptos estudiados intentaron, mediante sus 
diferentes métodos, reducir las desigualdades regionales, no obstante en realidad las ideas que se plantearon nunca se pusieron en práctica adecuadamente.

Key words:

Polonia, Planificación espacial, Desarrollo físico, Estructura espacial

JEL codes: O1; O18; O21; R1 
1. Introduction

Changes in Poland's political and economic system have combined with the country's accession to the EU to make the devising of new spatial development concepts a necessity. The choice of an appropriate strategy by which to develop the country's spatial structure is crucial for future generations, and for determination of Poland's place in Europe. In this process of selection, the major dilemma is - as often - to establish whether it is the priority of equality, or that of efficiency, which represents the best solution. If "efficiency" were to win out, then the decision would be to focus on the promotion of strong regions, thereby further enhancing spatial polarisation. On the other hand, if "equality" is chosen, the weaker regions are to be helped, with a view to inter-regional disparities being limited, in full awareness of the fact that what the strong regions are able to achieve will in this way be limited (Fig. 1).

According to the founders of the contemporary vision of the country's development, who have accepted the doctrine of polycentric concentration and diffusion, the reality of Polish life necessitates (and the need to seize a chance of escaping from civilisational backwardness dictates) that efficiency should be prioritised ahead of equality (Koncepcja...1999). In the view of proponents, it is necessary to come to terms with the market economy's natural tendency to generate polarised spatial development. The most direct route to obtaining more effective economic development is then perceived to lie in a focusing of socioeconomic activity in places most suitable for the location of capital. These include nodes, belts and zones of activity, entrepreneurship and innovation. With the help of the state, the latter are considered capable of driving wider diffusion of the said innovation, ultimately exerting an activating impact at the level of the spatial structure of the country as a whole. 


\section{Fig. 1}

In studying inequalities in spatial development, we continue to take account of the coreperiphery theories whose theoretical foundations were first put in place by F. Ratzel (1896), before gaining full development under J. Friedmann (1974). Cores are territorially arranged subsystems in society, standing out in their marked capacity to generate innovation. The peripheries are those regions outside the cores, whose development will nevertheless depend on them. In the opinion of J. Friedmann, an appropriate shaping of the spatial structure may simultaneously offer a chance to ease the core-periphery duality. Supporters of dependence theory in turn claim that regions' poverty does not reflect their isolation and limited spatial integration, but rather the asymmetry characterising relations with the economic system. Thus the benefits of development for the core do not extend to the peripheral areas.

The theory of poles of growth - above all linked with the name of F. Perroux (1955) also implies the existence of development-related inequalities. Poles of growth may be set against the "critical zones" considered to lag behind (as in Bański 1999). In turn, the classification of regions from L. Klaassen (1965) contrasts those of prosperity with areas of poverty.

Such issues of regional inequality have long been discussed and debated, a focus for a certain dissatisfaction or even anger being the sheer durability of the phenomenon in question. Proponents of the theory of equilibrium see existing differences in supply and demand for capital and labour as sufficient in themselves to bring about a reduction in developmental disparities between regions. Assuming that capital and labour are freely mobile between rich regions (A) and poor ones (B), investment will begin to flow from A to B, while workforce passes from B to A. In this way, inter-regional differences will in some way be evened out as time goes by. 
In turn, in the view of advocates of the theory of cumulative causality, regional disparities will only increase (as the benefits of a cheap labour force prove no match for the overall benefits agglomerations have to offer). There will thus be a compensatory shift adjusting for the high labour costs in region $\mathrm{A}$, while the outflow of workers from region $\mathrm{B}$ will limit the high costs of "outflow" to region A. Developmental disparities may therefore intensify.

A third solution is assumed by the theory of polarised development. The first stage in the process of economic development is deemed to be an increase in regional disparities and a concentrating of capital in several core centres. However, as development continues, a point is reached at which centres of growth are saturated, and investors' interest in other parts of the country begins to grow. This ultimately leads to a convergence of regional development. It is this theory that current concepts for spatial organisation in Poland make reference to.

The present article aims to analyse concepts for the spatial development of Poland, first and foremost as these have addressed the problem posed by a highly-disparate spatial structure in which regions of (at least) adequate development exist side by side with areas living in poverty, and in general located peripherally. It is the concepts emerging since World War II that have been looked at in developing this article's primary thesis - which is that, notwithstanding a desire on the part of all the studied concepts to even out regional disparities, the practical activity actually pursued in line with them has left in place the marked imbalance whereby the country continues to be divided into rich and poor regions.

The analyzed concepts (also referred to as plans or policies) are the basic documents formulating the state's key principles underpinning a national spatial management policy for the next dozen or so years. These concepts focus on policy, i.e. a deliberate effort to shape the national space in keeping with priorities of the country's developmental strategy. Also, they determine the relations between the government's and local authorities' spatial policy. These 
concepts cannot be treated as spatial planning documents, though they provide premises for drawing up projects comprising tasks carried out by the government within the framework of a national spatial management strategy.

It should be also stressed that these concepts had different status and role in the spatial policy of the country. A post-war concept was, for instance, a distinctly theoretical study not approved as an official governmental document and thus formed no basis for a national spatial management policy. Nevertheless, the study's premises were in many places congruent with the intentions of the then government. On the other hand, the concept being worked out in the 1990s was published and accepted as an official governmental document laying down the principles of the country's spatial management policy.

2. The vision of the period of Poland's reconstruction

In the century and a half over which Poland was subject to partitioning by neighbouring powers, the territories making up the country within its post-1945 borders were basically treated as peripheral. Under those circumstances, it is hard to envisage their having developed in any more planned way. Relatively speaking, it was the lands having been under the control of the Prussian Empire that progressed furthest in economic terms. The Austrian-controlled and Congress Kingdom (Russian-administered) parts were in a much worse position.

It is very much on account of what happened during the Partitions that the Poland of today continues to be afflicted by marked regional disparities in terms of the economy, the level of civilisational development and quality of life.

The years of Polish servitude and non-existence combined with the devastation of the First World War to ensure that the state finally re-established in 1918 was in urgent need of costly investment. Yet any more planned approach to this in the inter-War years was hindered, not only by the aforementioned economic and civilisational polarisation of Poland, 
but also more generally by the economic crisis affecting the whole world in the late 1920s and early 1930s.

Under these circumstances, what may be considered a rather impressive undertaking for the time was the construction of Poland's Central Industrial District, the goal being for important branches of industry to become located in the central part of the country (far from Germany), with economic activation stimulated in areas of "poverty". Seen in the context of the subsequent history, the Central Industrial District is one of the most courageous planning measures ever implemented in Poland, though a second important undertaking was the construction of the port in Gdynia, as well as of the coal line that linking it with Upper Silesia.

Ultimately, the Second World War made void the ambitious plans for Poland that might otherwise have been put into effect (war destroyed $65 \%$ of industrial plants, $35 \%$ of buildings, $55 \%$ of power stations and power lines, and $45 \%$ of machinery and facilities).

In the immediate aftermath of regained "independence" in 1945, Poland found itself beset with a number of urgent spatial planning tasks needing to be discharged. Thus 1946 brought the establishment of the Central Office of Spatial Planning (Główny Urzqd Planowania Przestrzennego), whose primary task was to prepare a long-term spatial plan for the country known as the Study for a National Plan (Studium Planu Krajowego). The main focuses here were on:

- the designation of land to meet the needs of different economic functions (agriculture, forestry, mining, etc.) and for the establishment of nature reserves,

- the distribution of the population and the network of the main urban centres,

- the distribution of networks of technical infrastructure,

- the division of the country into regions as a basis for dividing the state administratively (Toeplitz, 1978). 
The first phase of the Study involved work on the three subject areas of communications, industry and the settlement network. Urbanisation and industrialisation were assumed to be "attracted" by traffic routes, above all concentrating at points where these intersect. In connection with this, abstract transit directions across Poland were delineated, these being linked up with points of entry on to Polish territory. The directions established in this way and taking the form of belts were later made more precise through searches for existing or proposed transport routes. It was at the intersections between the most important of these that the largest urban centres were found, while the crossings between the secondary routes were locations for urban centres of regional significance. Appropriate economic (agricultural, forestry-related or tourist) functions were ascribed to areas lying between the belts.

A second main theme of the work involved the locating of industry. When the distribution of the main centres of production was analysed, it became clear that these were excessively concentrated, with the effect that creative energy was draining out of weaklyindustrialised areas. For this reason, the Study's authors were keen to advocate a more even distribution of industry - something they considered achievable through a deconcentration of existing industrial districts and the founding of new centres with this kind of profile.

Industry (especially heavy industry) was a basic factor behind economic development of the regions. Acknowledging the need to eliminate disparity in the level of development between different regions of Poland, the authors of the plan suggested creating new industrial centers. This was intended to stimulate economically the development of poorly industrialized areas, as well as attracting the population away from the overpopulated rural areas to urban centers.

The third subject of the distribution of the settlement network was also being worked on. Christaller's theory was invoked as a model for a hierarchical system of urban centres that 
was devised. The latter was adapted to the real distribution of towns and cities, the emerging settlement network being used to divide the country up into nodal regions (these in turn serving as a basis for a proposed administrative division).

The second stage of the Study focused mainly on agriculture and industry, these being transformed over three consecutive periods of reconstruction, industrialisation and urbanisation. Thus, in the case of agriculture, the first two phases involved allocation of the "excess" farming population to areas of land abandoned by the Germans, and subsequently to industrial areas. The urbanisation phase in turn anticipated the shaping of an ever-greater regional emphasis to agricultural output (Fig. 2). In the case of industry, the first phase entailed renewed start-up in production centres that remained in existence after the War, as well as the designation of non-industrialised areas. The second phase, in turn, involved the deconcentration of industry, and the third its ultimate dispersion.

In 1948, a wave of criticism of economic planning and of the concepts being implemented by the Central Office of Spatial Planning broke out. As A. Jezierski and C. Leszczynska (1997) state, the then Central Committee of the Polish Workers' Party claimed that planning made use of bourgeois methods of calculating national income, bringing about a reduction within that of the role being played by state industry. However, the 1949 reform of spatial planning brought an end to work on the Study for the National Plan. The Central Planning Authority and Central Office of Spatial Planning were both closed down. Called into being in their place was the State Economic Planning Commission (Państwowa Komisja Planowania Gospodarczego), which implemented decisions taken by the Party's Central Committee.

Over the next twenty years, planning objectives were more likely to be pursued in relation to divisions of the national economy than territorial ones. For this reason, objectives and tasks devised as part of the Study could never be put properly into effect. The Study may 
be said to have been more theoretical than practical in character, pointing to the potential and high level of skill of planners, as well as shaping ways of proceeding for those who would implement future concepts.

The authors of the plan, who suggested developing the new industrial centers in the economically backward areas as well as a balanced settlement network, opted for prioritising equality ahead of efficiency. Despite the fact that the plan was not oficially put into effect, a lot of its solutions were actually implemented. This concerns primarily deconcentration of industry and 'the enriching' of the settlement network with new cities (for more information see chapter 2).

Fig. 2

Post-War planning was no longer deemed to reflect interplay on the market, but rather decisions taken at central level. These deployed the labour force, as well as determined what would be produced and for whom, and where industry and all fundamental elements of infrastructure would be located. Thus, unlike the market economies, communist countries could ostensibly activate poorly-developed regions simply by locating new industrial development there. However, the activation of regions was inflexibly equated with the location and development there of (heavy) industry, as opposed to any other possible means. Indeed, even the technical and social infrastructure that might have raised the effectiveness of investment in plants was very much overlooked.

According to K. Dziewoński and B. Malisz (1978), it was the wartime destruction that made a radical makeover of Poland's spatial structure possible, the aims pursued being the evening-out of inter-regional disparities and the decentralisation of industry. Alas, the extremely pressing day-to-day needs of the country at that point made it necessary for 
production to be started up - and assets restored - however and wherever that was at all possible. The regrettable side-effect of this was for the previously-existing spatial structure to be largely reinstated. Thus, just several years after the War's end, the spatial structure of Poland was characterised by major divides in terms of both social and economic development.

Basic elements in the state's spatial structure at that time were the network of communications linking the most important urban centres, as well as two main axes of industrial development (Fig. 3). Where the communication linkages were concerned, there was a very visible absence from the north of the country, as compared with a tendency towards concentration in the centre. The two axes of industrial development referred to passed through Upper Silesia, at that time the country's main pole of development. Thus, disparities centred first and foremost around a divide between the poor east and the better-invested-in west. There were also glaring disparities in the distribution of the main urban centres, these being concentrated in central and western parts of Poland.

Fig. 3

Later years enjoyed a rapid rate of industrial development and urban population (Figs. 4, 5). The 1950-1955 Six-Year Plan assumed the development of heavy industry, but investment overstretch ensured a steady slowdown in the rate of investment, to the point where disquiet in society was even aroused. Nevertheless, new industrial centres did emerge in subsequent years, the result being a more even distribution of industry nationally, which is to say, a process of deconcentration.

Fig. 4 
Fig. 5

A result of these transformations was that the configuration of main elements to the country's spatial structure gained several new medium-sized urban centres, which assumed new functions as urbanisation progressed. Towns and cities came to be linked together by a denser communications network, though the heaviest concentration continued to characterise central Poland. While the intended, more even distribution of industrial plants was achieved to some extent, Silesia remained the clear dominant where this branch of the national economy was concerned. Nevertheless, a wider, more-highly-industrialised area did arise, this occupying a large triangular-shaped area on the map of Poland (Fig. 6). All the major urban agglomerations were to be found within this zone.

Fig. 6

\section{The "Poland 2000" Visions}

In the late 1950s, a discussion on the system and methods of spatial planning got underway, the view that came to dominate being that planning should link up with a prospective programme for the economic development of the country, and have a three-level division into national, regional and local planning. The breakthrough here came with the enactment of the 1961 Act on Spatial Planning, which set out the objectives and tasks of spatial planning and physical development, as well as types of plan and the principles underpinning their elaboration, and the competences to be conferred upon the bodies drawing them up.

However, by 1970, the consequences of years of flawed economic management were inevitably making themselves felt, the general dissatisfaction within Polish society being 
sufficient to generate change within the governing elite (beginning of the "Edward Gierek period"). This fed through into an amended national economic policy, under which outlays on industry grew, and work commenced on the building of new factories funded by foreign loans. The early 1970s were thus a period of the maximal dispersal of industrial investment, leading to a narrowing of the developmental gap between regions.

Work on a new national plan of spatial management was undertaken in 1971, and was accompanied by renewed debate among scientists and planners (Rozwój... 1971, Prognozy rozwoju... 1971). In 1974, the Governmental Praesidium adopted the preliminary draft of a future plan for the country's spatial organisation and physical development up to 1990 (Plan... 1974). The conceptual work here took in the settlement network, industry, agriculture, environmental protection, etc. The most interesting forecasts concerned the development of the settlement network, including the main urban settlements. Plans for the development of urban agglomerations are noteworthy, their realistic predictions referring to a national population of 38 million by 2000 , employment of $17 \%$ of the professionally active population in agriculture and forestry, the automation and computerisation of output, and enhanced concentration and urbanisation in the spatial structure, with simultaneous deconcentration phenomena in agglomerations (Leszczycki, Eberhardt and Heřman, 1971).

In the view of the authors, what were at that time being created within spatio-economic structures were integrated settlement complexes in the form of large cities in which development potential was accumulating, while strong interlinkages of a social and economic nature were making themselves felt along the main transport routes. Agglomerations were gradually absorbing the small towns and villages in their vicinity. Thus, the primary skeleton of the country's spatio-economic structure was to be provided by a polycentric system of nodes and belts, within which agglomerations were to serve as main nodes (Heřman and Eberhardt, 1973). 
Overall, the concept indicates directions to the development of urban settlement structure. However, some of its assumptions could not be complied with because of the economic crisis, difficulties with the system of central economic planning and the ongoing decline in the importance attached to large industrial plants. In the event, the sizes it anticipated for urban-industrial agglomerations and central agglomerations were too large. There was also a lack of proposals for strengthening the urban settlement system in the north and east, i.e. those areas displaying marked disparities when set against the southern and central regions. As B. Malisz (1984) stressed, the concept for the development of urban agglomerations is characterised by a lack of faith in the effectiveness of spatial planning and, although this is most probably realistic, it is not very desirable from the social point of view. Another concept concerning the transformation of the settlement network in the Plan was that devised by B. Malisz (1978). Its main assumption was that innovation (as the basic factor in economic development) progresses along certain belts or routes, since it is along these that the best conditions for the development of industry exist. It is in turn at the points where these intersect that we find the most favourable conditions for the establishment of centres for the services. The development of towns and cities increases the significance of the routes, and that in turn affords yet further opportunities for development. A second assumption in turn holds that human progress is guided by the principle of least effort (i.e. that attempts to achieve goals are made with the smallest possible inputs of energy and labour). This means that the spatial structures created are permanent, and comprise linear, point and zonal elements. The point (or nodal) elements join the linear (belt-like) elements in forming the skeleton for the spatial structure. It is in the nodes and belts that intensive human economic activity is concentrated.

Discussion of the above concepts stimulated work on the Plan for the spatial management of the country up to 1990 (Plan przestrzennego zagospodarowania kraju do 
roku 1990). Its ambitious visions were verified by the then central authority, for the plan had above all to take account of the assumption that Poland's economic development would be dynamic. Ultimately, the aims regarding development of the settlement network found themselves based around the "system of moderate polycentric concentration". Urban centres were to develop at varying speeds, i.e. with slow growth of the agglomerations already developed, compared with intensive growth of developing agglomerations, potential agglomerations and centres of national significance. This measure was thus a favourable one from the point of view of the balancing of regional development.

The Plan adopted a series of other provisions on socioeconomic life, the overall aim being to limit the role of industry as the only factor in the development of regions, while at the same time reinforcing the positions of agriculture and tourism. The main strategic objective was to shift part of the industrial potential from the south of the country to northern and eastern areas. Industry was to develop there, in smaller urban centres in particular. Where the agricultural economy was concerned, the assumption was of a relatively even spatial breakdown to the structure of the basic elements of agricultural output. There were very ambitious intentions when it came to the development of the road network, first and foremost the motorways. By 1990, there were to have been both north-south and east-west motorways, while the post-1990 period was to have focused on the construction of several new sections of motorway not even considered in planning today (Fig. 7).

It can be claimed that a priority of a balanced development of regions played a superior role in that plan. Indicative of that was especially the suggested system of a moderate polycentric concentration favouring a large group of medium-sized cities that were to develop dynamically. It was also congruent with the national administrative reform of 1975 that led to replacing the three-level division (voivodship-poviat-commune) with two-level one (voivodship-commune) and to establishing the new 49 ones in place of the then existing 14 
voivodships (forming the regional centers of development on the basis of the urban agglomerations and medium-sized cities). This was a clear indication of simplification and deconcentration of the system of administration. A great many economists were not convinced of the necessity to bring into existence such a great number of voivodships, a large portion of which were entities poorly developed socially and economically. These underdeveloped voivodships were unable to compete with well-developed entities based in powerful industrial centers or in large urban aglomerations. Subsequent administrative reform carried out in 1999 (at the same time a new concept of a national spatial management policy was accepted), was, to a large extent, a return to the earlier division (16 voivodships and the three-level administrative division) promoting again first and foremost major urban agglomerations.

Fig. 7

While the Plan did win the acceptance of the then political authorities, it was even so implemented to only a very limited degree. This reflected inherent internal weaknesses of the Plan itself, the "over-scaling" of its economic assumptions, criticism of the idea that agglomerations might develop excessively, the fact that large industrial developments were often sited in contravention of the Plan's assumptions, incompetent decisionmaking at the centre and many other external factors.

As has been noted already, very large outlays went on the development of Polish industry, much of the money in question being targeted at regions in need of economic activation. Inevitably, the results were less dramatic than had been anticipated, first and foremost because of the stubborn persistence with the heavy industry option, as set against rather limited expenditure on means of consumption. While the solution of the huge industrial 
plant was turned to again and again, most of the weakly-developed areas into which these were slotted lacked the necessary background conditions for such investments.

Thus, once again, a concept for the country's spatial development prepared by a large team of scientists and practitioners emerged as an "on paper" study, not more readily "translatable" or applicable in practice. The scientific diagnosis of the state of management of the country's spatial structure, together with a proposal as regards the solving of some of the problems posed by excessive inter-regional disparities in development, never actually lived to see the proper solutions implemented. The country was faced with an ever-deeper economic crisis and an associated ongoing intensification of spatial polarisation. Relatively the best economic situation was that facing the large urban agglomerations and industrial districts. In contrast, there was an intensification of unfavourable population processes in the eastern regions in which agriculture still prevailed (notably out-migrations and an ageing of the population remaining in the countryside).

Introduced in 1975, a two-tier structure for field-based organs of authority and the state administration (voivodships and gminas) necessitated changes in the system of spatial planning. The national spatial management plan represented an integral part of a prospective plan of socio-economic development, as well as serving as a basis for the drawing up of lower-order plans (for macroregions, voivodships, towns and gminas).

Further work done in the 1980s aimed to determine the premises that would underpin a new national plan of spatial management. The political and economic situation at that stage proved unfavourable to the dreaming up of far-reaching plans, hence the focus in published research results and expert opinions on criticism of the earlier planning activity and on the search for new developmental pathways where spatial planning and regional studies were concerned (Problemy polskiej przestrzeni 1982, Przestrzenna organizacja...1981, Przeksztatcenia miast...1982, Strategia uprzemystowienia...1982). 


\section{A contemporary concept of spatial organisation}

The 1980s were thus a time of rather slow growth in industrial investment, ensuring rather little change in the structure of Poland's spatial organisation. In contrast, the years from 1989 onwards saw a now-free Poland faced with a quite new political, social and economic reality that required (and did indeed generate) a process of radical transformation that swept through all the elements making up the state as a socioeconomic entity. A collapse of industrial output was one of the less desirable results, reflecting a marked drop in society's purchasing power, reduced demand for investment and supply goods, an influx of Western products and a severing of some cooperative linkages (Wieloński 2005). Fortunately, the decline in industrial output was not prolonged (see Fig. 5). It began to bottom out as early as in 1992, though the nascent economic revival was mainly based around services and commerce, the role played by industry in the national economy having declined irrevocably.

Post 1989, the opening up of borders and great desire on the part of Poland to return to the fold of Western European civilisation underpinned ever-fuller incorporation within continent-wide spatial structures. While the country's geopolitical location had never failed to be a matter of significance, political intervention under the previous system had left Poland in a less-than-ideal position as regards the physical development concepts, and one which it would not necessarily have occupied had all other things been equal. Today, location is of course one of the most important elements conditioning the development of Polish space.

The process of (European) "Unionisation" (entailing adaptation, harmonisation and approximation of Polish space to the conditions and parameters in force in the EU) resulted in Polish space becoming European Community space (Kukliński 1997). Indeed, there has been an important role to be played in this context, since the eastern part of Poland is at the same 
time an external frontier of the EU. This makes it a venue for cooperative cross-border ventures between Eastern Europe (i.e. the area beyond the borders) and the Union as a whole.

A number of opportunities are thus afforded by Poland's location on the continental scale and regionally (i.e. in Europe in general and its Central and Eastern part in particular), even though this may also represent a source of conflict. Both the former and the latter follow from a location sandwiched between Germany as a major economic player in the world, and Russia - as a global (super) power.

In the view of J. Kołodziejski (1996), Poland has a beneficial geographical and economic location, allowing it to serve as an important focus in the integrating space of Central and Eastern Europe. Among other things, such a location facilitates the flow of innovations, goods and persons, creating favourable conditions for the locating of enterprises and for the inclusion of Poland's economy within European competitive space. It also opens up potential where tourism and environment-related activities in Poland's natural space are concerned.

Polish space is thus treated as a keystone of Europe's integration processes, in both the vertical and horizontal configurations. Ongoing in the east-west direction is a process of integration involving the EU on the one hand and the Euro-Asiatic Commonwealth of Independent States on the other, while in the north-south direction, Baltic Europe is proceeding to integrate with South-Eastern Europe (Kołodziejski 1998).

However, the impression continues to be that the north-south direction plays a less important role in Poland than the east-west. For this reason, that "keystone" location between Europe's Baltic Region and South-Eastern Europe (mainly Romania and Bulgaria) is better treated as an idea - and opportunity, than as a fact - or existing strength. The Baltic Sea in the north and mountainous areas in the south continue to present major barriers to all kinds of "movements" or "flows" in this direction. Moreover, the socioeconomic potential of the 
neighbours to the north and south is at best marginal when set against those of Russia plus Belarus and Ukraine in the east, as well as Germany and other states beyond in the west.

Equally, the concepts for Europe's spatial development emerging in the late 1980s and early 1990s did rather tend to place Poland on the periphery of any areas playing a more major role in continent-wide social and economic development. In effect, this was just another one of those post-Communist countries linked but weakly with EU space. This kind of attitude is equally discernible in the so-called "European banana" or "Blue Star" concepts, or indeed as regards the so-called "islands of innovation".

While things have moved on, Poland's incorporation into the EU system as regards spatial structure has done little to change that peripherality of location. The eastern part of the country is a true margin of the European Union, resembling other marginal areas on the continent in lacking opportunities for dynamic development.

The systemic transformation made it imperative to work on new legal solutions as regards planning and physical development. 1994 saw the adoption of a new Spatial Planning Act that took account of solutions widely accepted and applied in Europe (e.g. the principle of ownership protection). There was also a decentralisation of tasks as regards spatial planning, including far-reaching transfer thereof to municipal level.

Poland post-1989 found itself in a new socioeconomic reality that required diagnosis and a new look at its spatial structure. New research was thus taken up so that an up-to-date document setting out state policy on spatial development and physical planning over the upcoming 20 years might be drawn up. Work on the "National Spatial Arrangement Policy" (Koncepcja polityki przestrzennego zagospodarowania kraju) was completed in 1999.

As the Policy makes clear, the key dilemma for physical development policy in Poland continues to lie with its capacity to reconcile contradictory postulates involving competitiveness and efficiency on the one hand, equality and justice on the other. Nowhere, 
however, can be found clearly expressed opinion of the authors of the Policy about the choice of a national spatial managment policy. One may have an impression that a 'golden mean' is being sought. The authors of the Policy focus on efficiency, if maintaining steadfastly that this does not denote acceptance of further spatial polarisation. Equally, they are firm in their conviction that their choice (of efficiency) is the absolutely necessary one to make in the face of Polish realia, offering as it does the best chance of an escape from backwardness. The attempt made to reconcile opposing standpoints on competitiveness and equality depends on a fundamental principle that balanced development may engender efficiency. The concentration of socioeconomic activity in places of the greatest economic potential offering most to investors is to effect this balancing of development nationwide, over the longer time perspective.

The thrust to such thinking is conceptualised synthetically in the sustainable development model (Fig. 8). To be distinguished within this are three main spatial elements, i.e. potential poles of polarisation, potential belts of accelerated development and potential zones of multifunctional development with a zone of accelerated development.

The poles of polarisation are to be: the capital city metropolis (competing with Vienna, Prague and Budapest, for example), the so-called Europolises (The Gdańsk-Gydnia-Sopot Tri-City, Poznań, Kraków, Wrocław - and potentially also Szczecin, Łódź, Katowice, Lublin, Białystok, Rzeszów and Toruń-Bydgoszcz) and the national, supraregional and regional centres of the balancing of development. Through the process of international competition, the potential poles of development will create ever stronger nodes of innovation anticipated to have a nationwide impact.

The potential belts of accelerated development lie along the international and national systems of technical infrastructure, above all including the system of motorways and main roads, as well as the rail lines. What is noteworthy here is the relatively even distribution of 
these belts across the country. Socioeconomic activity that is competitive on the European scale will be concentrated in the zone of accelerated development. The model for the balancing of development contained in the National Spatial Arrangement Policy is enriched by a further element in the form of the so-called Polish pole of development, taking in Warsaw, Kraków, Wrocław, Poznań and the Tri-City and emitting positive impulses into the surrounding areas.

The National Spatial Arrangement Policy has represented a basis upon which lower tiers of administration have drawn up their own documents of a similar nature. Thus, the regional assemblies (sejmiki) in the voivodships enact their voivodship development strategies and physical development plans that should be in line with the Policy. In turn, the devising of Studies on the conditioning and directions to physical development and of Local physical development plans is a gmina-level matter.

In line with its very generalised character, the voivodship physical development plan is not actually a local legal act, and does not impinge upon the entitlements enjoyed by gminas. In turn, the Local physical development plan enacted by the gmina does stand out among all the planning documents in constituting local law. Above all, it contains information as to the designations of given areas of land, and the principles and conditions underpinning the assignment of land to different use categories.

In view of the brief period of time that has elapsed since drawing up the Policy, it is difficult to point out its practical meaning to spatial planning. Its acceptance occurred at the same time with implementation of the national administrative reform aiming to reintroduce large voivodships (on the basis of 49 voivodships, 16 new ones were formed). It may be pointed out that a priority of efficiency played here a crucial role. Thus, competitve and economically powerful agglomerations (now capitals of voivodships) were strengthened at the 
cost of regional growth centers which, as a result of this reform, lost a part of their administrative and economic functions.

Fig. 8

5. The impact of the concepts on the image of spatial structure

The contemporary image of the spatial structure of Poland results from multiple processes as well as political, social and economic phenomena. The three concepts for spatial organisation, considered here, contributed also to the formation of this image. In view of the fact the the concepts arose in various periods of political and economic development of the country, their objectives and challenges differed. Likewise, they had differentiated practical significance in terms of shaping the structure of spatial organisation. It should be emphasised that in the respective periods of preparation of all the three concepts a number of original studies were elaborated, which constituted important contributions to the knowledge and conceptual wealth of the domain of Polish spatial economy.

From the first concept (Study for a National Plan, Studium Planu Krajowego) no official planning document resulted, and so we can state that this concept had the nature of a theoretical study (a vision of development), which did not turn into practice. The elaborates worked out did not produce a consistent document, whose goals would have then be implemented. Yet, the prerequisites formulated and the adopted methods of work exerted an influence on the later planning undertakings. The fundamental challenges to this first concept were:

- deconcentration of industry,

- development of the main elements of the infrastructure networks,

- designation of the directions of development of the regions, 
- indication of the main directions of migrations.

All of the objectives mentioned aimed at optimisation of the spatial structure of the country and alleviation of the regional development differentials. Given that the work on this concept was interrupted, it can hardly be assessed. A part of the proposals that it contained were, however, being implemented in the following years.

The concept named "Poland 2000" had a different character and the methodology of its preparation differed, as well. The output from the "intellectual storm" among the representatives of academia and practice was constituted by the elaboration of a dozen or so original concepts for the development of the spatial structure of the country, which made the theoretical basis for the official document Plan for the spatial management of the country up to 1990 (Plan przestrzennego zagospodarowania kraju do roku 1990). The ultimate referee and editor of the document was the then state administration, subordinated to the Party, and so this one turned out to be not a realistic, but a "wishful" elaborate. The most important objectives, formulated in the document were:

- the concept of the moderate polycentric concentration,

- the differentiated rate of growth of urban centres,

- deconcentration of industry, with emphasis on the development of small industrial plants,

- development of modern transport network.

Economic crisis of the country and deployment of large investment projects "outside of plan" caused that the practical significance of the concept was limited. That is why the differences in the levels of regional development, instead of getting smaller, deepened yet.

The third of the concepts considered, the National Spatial Arrangement Policy (Koncepcja polityki przestrzennego zagospodarowania kraju) had a broader dimension, for it referred, as well, to the position of Poland in Europe and the resulting thereof opportunities 
and threats. One of the dilemmas addressed in the document was to reconcile, on the one hand, competitiveness and efficiency, with, on the other hand, balanced regional development. The authors of this concept, though, concentrate on the former. They consider as the fundamental contemporary challenges the following ones:

- taking advantage of the :interface" position of Poland;

- development of infrastructure (mainly of roads),

- development of agglomerations as the poles of polarization.

These challenges clearly indicate the choice of efficiency ahead of equity. In this connection one could hardly expect the process of balancing of the regional development to take a proper course.

When the contemporary spatial structure is analysed, several fundamental elements can be distinguished, representing a particular kind of primary fabric for all the discussed planning studies. Included here first and foremost are the settlement network and the system of main transport routes. Within the former, the most important role is played by the mature agglomerations (Warsaw, Poznań, Kraków, Łódź, Wrocław, Gdańsk and Katowice), as well as the growing agglomerations (Bydgoszcz-Toruń, Szczecin, Białystok and Lublin). In turn, the key features of the system of transport routes are the existing and planned motorways, as well as the railway main lines.

It is upon the foundation this basic fabric provides that the central and western parts of Poland are forming up into a contiguous area of elevated developmental potential (Fig. 9). Within this are northern, central and southern areas of accelerated development that may be deemed capable of drawing benefit (or less charitably "taking advantage" or even “exploiting”) other regions. They are a "magnet" attracting investment, capital and people, their economic and social potential being sufficient to ensure competitive interaction in the global market place, alongside other areas of Europe. In the future, they will enlarge - most 
probably as belts, and most especially as ones with an east-west orientation. The economic position of such growth areas is strengthened by planned motorways, as well as the redevelopment of national and international air links.

The areas of elevated development potential are surrounded by others that may be considered to be "benefited from" - or "taken advantage of/exploited", to use stronger language. In the main, these are within the economic peripheries of the country (Bański 2007). Their social potential is being sucked away - mainly by areas of accelerated development. The whole post-War period has thus been associated with an outflow of the young, best-educated and most entrepreneurial to more favoured areas.

In spite of several decades of struggle to reinforce the poorer regions economically, it has not proved possible to dislodge the spatial polarisation existing across Poland. This is confirmed by data on own income to the budgets of gminas (local authorities), this first and foremost comprising real-estate taxes, fares from means of transport and income tax from natural and legal persons. Weakly-developed regions are characterised by a slower rate of increase in own income per inhabitant. The voivodships of eastern Poland (Lubelskie, Podkarpackie, Podlaskie and Świętokrzyskie) are among the poorest regions anywhere in the EU25, and are characterised by low own incomes to gmina budgets and relatively low rates of increase thereof.

Tab. 1

It is nevertheless thought of as important from the points of view of spatial planning and regional development strategies that support should be extended to areas of stagnation, whose development should be strengthened by way of deft policymaking. The main elements in the balancing of development in these areas should be the regional urban centres like Szczecin, 
Białystok, and Lublin plus Rzeszów. These are suited to a role in stimulating progress and innovation because, as well as being administrative, service-related and commercial centres, these cities are also home to leading academic institutions.

An equally important role in any future balancing of development might be played by the belts of growth forming up along the Warsaw-Białystok-Suwałki, Warsaw-LublinZamość, Białystok-Lublin-Rzeszów, Szczecin-Koszalin-Gdańsk and Szczecin-Legnica transport routes. The development of these belts will need to engage external resources, in particular to allow their technical infrastructure to develop and to ensure that investment in innovation is forthcoming (Bański 2005). In addition, a good feature of the belts may be their participation in international commerce, providing that steps are taken to limit a possible "tunnel effect", whereby the routes come to serve as nothing more than passive conduits for transit traffic.

Fig. 9

\section{Conclusions}

Over the last 60 years, three fundamental concepts for the spatial development of Poland have been drawn up. The most far-sighted and bold of these arose in the immediate aftermath of the Second World War, its primary objectives being to decentralise industry and to reduce inter-regional disparities as regards development. Unfortunately, the requirement to rebuild even the most basic elements of the then spatial structure made it impossible to attain the kind of ambitious goals the concept engendered. Nevertheless, the outlined directions of activity were pursued and worked on to a greater or lesser extent over the entire post-War period. 
The 1970s boasted a wide range of different, more or less fully-developed concepts for the country's spatial development. The discussions over these were the stimulus underpinning the Plan for the Spatial Management of the Country to 1990 (Plan przestrzennego zagospodarowania kraju do 1990 r). The adopted system of moderate polycentric concentration and task of shifting part of the country's industrial potential from the south to weakly-developed regions in the north and east both attest to the attempt that was being made to even out the spatial structure. Unfortunately, the Plan proved over-optimistic in its assumption of very dynamic economic development in Poland, falling prey to the then ubiquitous propaganda of success. The later economic crisis again rendered implementation of most of the proposed tasks impossible.

The contemporary concept for the development of the country's spatial structure is in turn founded upon the theory of polarised development. This assumes the gradual spread of innovation and other developmental factors from areas of growth (dynamic development) into what is broadly understood as "the periphery" (i.e. areas of stagnation or slow development), the aim being for a convergence of regional development to be attained. However, in this regard, Poland would only seem to be taking its first steps on a long road, in which the consequences of areas being "sucked dry" are continuing to prevail over the more beneficial effects envisaged as the process of "propagation" continues.

The assumption behind all of these concepts is that developmental disproportions between regions need to be evened out. Various methods of attaining that goal have been devised. For example, the concept applying in the period of the country's post-War reconstruction assumed a transfer of large investments in industry into the marginal areas, this being thought likely to dynamise development. In turn, today's concepts advocate a balancing of development by means of competition and the polarisation of socioeconomic activity in selected nodes and developmental belts that gradually come to encompass ever larger areas. 
In the face of all this, the unfortunate truth is that the whole post-War period has seen intensifying spatial polarisation, leading in extreme cases to the emergence of areas of genuine poverty. While some of the tasks laid down in communist-era planning documents were even completed, the fruits of those labours were not strong enough to tackle spatial disparities existing across Poland. And - when all kinds of changes in the country's system of administration at last became possible, along with changes in the socioeconomic structure and a completely new global geopolitical situation in which Poland was now free to operate - no new planning vision for the future of Poland appeared. It was almost as if concepts were afraid to put into words the need for change in the new circumstances.

Poland faces new and important challenges centering on the race to catch up with Western Europe and be incorporated into the global economy. The new processes and phenomena associated with those objectives are steadily changing the internal face of the country. Among them are depopulation processes, the growth of metropolises, the search for new energy sources and so on. The influx of a large wave of foreigners is to be expected in the near future. These and other processes have combined to ensure that a start to work on a new concept for spatial organisation has now been made at last. The theoretical prerequistes and the first version of the document were elaborated at the Institute of Geography and Spatial Organisation of the Polish Academy of Sciences in 2008. After social consulting and verification at the Ministry of Regional Development this document shall become the basis for elaboration of the new Concept for the spatial development of the country 2008-2033. 


\section{References:}

Bański, J., (1999) „Obszary problemowe w rolnictwie Polski” (Problem areas in Polish agriculture), Prace Geograficzne (Geographical Studies), 172, Instytut Geografii I Przestrzennego Zagospodarowania PAN, Warszawa.

Bański, J., (2005) "Suburban and peripheral rural areas in Poland - the balance of development in the transformation period", Geograficky casopis, 57, 2, pp. 117-130, Slovak Academic Press, Bratislava.

Bański, J., (2007) „Obszary wiejskie w planowaniu przestrzennym” (Rural areas in spatial planning), Urbanista, 2 (50), pp. 10-14, Towarzystwo Urbanistów Polskich, Warszawa.

Dziewoński, K. and Malisz, B. (1978) „Przekształcenia przestrzenno-gospodarczej struktury kraju" (The transformations of the spatio-economic country's structure), Studia KPZK PAN (Studies of the Committee on Spatial Economy and Regional Palnning Polish Academy of Sciences), 62, Panstwowe Wydawnictwo Naukowe (PWN), Warszawa.

Friedmann, J., (1974) „Ogólna teoria rozwoju spolaryzowanego” (A general theory of polarised development), Przeglad Zagranicznej Literatury Geograficznej (International Geographical Literature Review), 1-2, pp. 18-33, Instytut Geografii i Przestrzennego Zagospodarowania PAN, Warszawa.

Herman, S., and Eberhardt, P., (1973) „Prognozy przemian osadnictwa miejskiego Polski” (Forecast of changes in Poland's urban settlement system), Biuletyn KPZK PAN (Bulletin of the Committee on Spatial Economy and Regional Palnning Polish Academy of Sciences), 78, Panstwowe Wydawnictwo Naukowe (PWN), Warszawa.

Jezierski A., Leszczynska C., (1997) “Historia gospodarcza Polski” (Economic history of Poland), Key Text, Warsaw. 
Klaassen, L., (1965) “Area Economic and Social Redevelopment: Guidelines for Programmes", OECD, Paris.

“Koncepcja polityki przestrzennego zagospodarowania kraju” (National Spatial Arrangement Policy) (2001) Monitor Polski 26, pp. 503-595, Prezes Rady Ministrów, Warsaw.

Kołodziejski, J., (1996) „Polska przestrzeń w europejskiej perspektywie XXI wieku” (Polish space from a 21st-century European perspective), ELIPSA, Warsaw.

Kołodziejski, J., (1998) „Koncepcja polityki przestrzennego zagospodarowania kraju” (National Spatial Arrangement Policy), Nauka (Science), 3, pp. 49-82, Polish Academy of Sciences, Ossolineum, Warszawa.

Kukliński, A. (ed.), (1997) „Polska przestrzeń w europejskiej perspektywie XXI wieku” (Polish space from a $21^{\text {st }}$ century European perspective), Biuletyn KPZK PAN (Bulletin of the Committee on Spatial Economy and Regional Palnning Polish Academy of Sciences), 178, Polish Academy of Sciences, Warsaw.

Leszczycki, S., Eberhardt, P. and Herman, S., (1971) „Aglomeracje miejsko-przemysłowe w Polsce" (Urban-industrial agglomerations in Poland) 1966-2000, Biuletyn KPZK PAN (Bulletin of the Committee on Spatial Economy and Regional Palnning Polish Academy of Sciences), 67, Panstwowe Wydawnictwo Naukowe (PWN), Warsaw.

Malisz, B. (ed.), (1978) „40 lat planowania struktury przestrzennej Polski” (40 years of planning Poland's spatial structure), Studia KPZK PAN, (Studies of the Committee on Spatial Economy and Regional Palnning Polish Academy of Sciences), 64, Panstwowe Wydawnictwo Naukowe (PWN), Warszawa.

Malisz B., (1984) „Trzy wizje polskiej przestrzeni” (Three visions of Polish space) [in:] A. Kukliński (ed.), „Gospodarka przestrzenna Polski. Diagnoza - rekonstrukcja - prognoza” (Poland's spatial management. Diagnosis-reconstruction-prognosis), Biuletyn KPZK PAN 
(Bulletin of the Committee on Spatial Economy and Regional Palnning Polish Academy of Sciences), 125, pp. 6-45, Panstwowe Wydawnictwo Naukowe (PWN), Warszawa.

Perroux, F., (1955) “Note sur la notion de „pôle de croissance”, Economie Appliquée, 8, 1-2, pp. 307-320, Paris.

“Plan przestrzennego zagospodarowania kraju do roku 1990” (A Plan for the Country’s Spatial Management up to the Year 1990), (1974) Biuletyn KPZK PAN (Bulletin of the Committee on Spatial Economy and Regional Palnning Polish Academy of Sciences), 85, Panstwowe Wydawnictwo Naukowe (PWN), Warszawa.

„Problemy polskiej przestrzeni” (Issues of Polish space), (1982) Biuletyn KPZK PAN

(Bulletin of the Committee on Spatial Economy and Regional Palnning Polish Academy of Sciences), 118, Panstwowe Wydawnictwo Naukowe (PWN), Warszawa.

"Prognozy rozwoju sieci osadniczej" (Forecasts for the development of the settlement network). Polska 2000, (1971) Komitet Badań i Prognoz „Polska 2000” PAN (the ”Poland 2000" Research and Forecasting Committee of the Polish Academy of Sciences), Ossolineum, Warszawa.

„Przestrzenna organizacja gospodarki polskiej. Próba analizy krytycznej” (The Spatial Organisation of the Polish Economy. Attempt of a Critical Analysis), (1981) Biuletyn KPZK PAN (Bulletin of the Committee on Spatial Economy and Regional Palnning Polish Academy of Sciences), 117, Panstwowe Wydawnictwo Naukowe (PWN), Warszawa.

"Przekształcenia miast na tle przemian urbanizacyjnych" (The transformation of towns and cities against the background of urbanisation-related changes), (1982), Biuletyn KPZK PAN (Bulletin of the Committee on Spatial Economy and Regional Palnning Polish Academy of Sciences), 121, Panstwowe Wydawnictwo Naukowe (PWN), Warszawa. 
Ratzl F., (1896) „Die Gesetze des raumlichen Wachstums der Staaten“, Petermanns Mitteilungen, 42, 103.

„Rozwój społeczny Polski w pracach prognostycznych” (Poland's social developnent in forecasts), (1971) Ksiażka i Wiedza, Warsaw.

"Strategia uprzemysłowienia a proces urbanizacji" (Industrialisation strategies and the urbanisation process), (1982) Biuletyn KPZK PAN (Bulletin of the Committee on Spatial Economy and Regional Palnning Polish Academy of Sciences), 119, Panstwowe Wydawnictwo Naukowe (PWN), Warszawa.

Toeplitz K. L., (1978) "Pierwszy Plan Krajowy” (The First National Plan), in B. Malisz (ed.), „40 lat planninga struktury spatialej Polski” (40 years of planning Poland's spatial structure), Studia KPZK PAN (Studies of the Committee on Spatial Economy and Regional Palnning Polish Academy of Sciences), 64, pp. 23-43, Panstwowe Wydawnictwo Naukowe (PWN), Warszawa.

Wieloński A., (2005) „Geografia przemysłu” (The Geography of Industry), Wyd. UW, Warszawa. 
Tables

Table. 1. Own income to gmina (local authority) budgets in selected voivodships, expressed per inhabitant

\begin{tabular}{|l|c|c|c|c|}
\hline Voivodship & $\begin{array}{c}1995 \\
(\mathrm{PLN})\end{array}$ & $\begin{array}{c}2000 \\
(\mathrm{PLN})\end{array}$ & $\begin{array}{c}2006 \\
(\mathrm{PLN})\end{array}$ & $\begin{array}{c}\text { Change } \\
1995-2006 \\
(1995=100 \%)\end{array}$ \\
\hline Łodzkie & 188 & 678 & 1151 & 614 \\
Mazowieckie & 305 & 1176 & 2167 & 711 \\
Wielkopolskie & 186 & 664 & 1167 & 626 \\
Pomorskie & 230 & 782 & 1462 & 636 \\
Lubelskie & 153 & 463 & 761 & 497 \\
Podkarpackie & 143 & 448 & 761 & 531 \\
Podlaskie & 150 & 471 & 885 & 589 \\
Swiętokrzyskie & 152 & 481 & 791 & 519 \\
\hline
\end{tabular}

Source: Central Statistical Office 
Figures

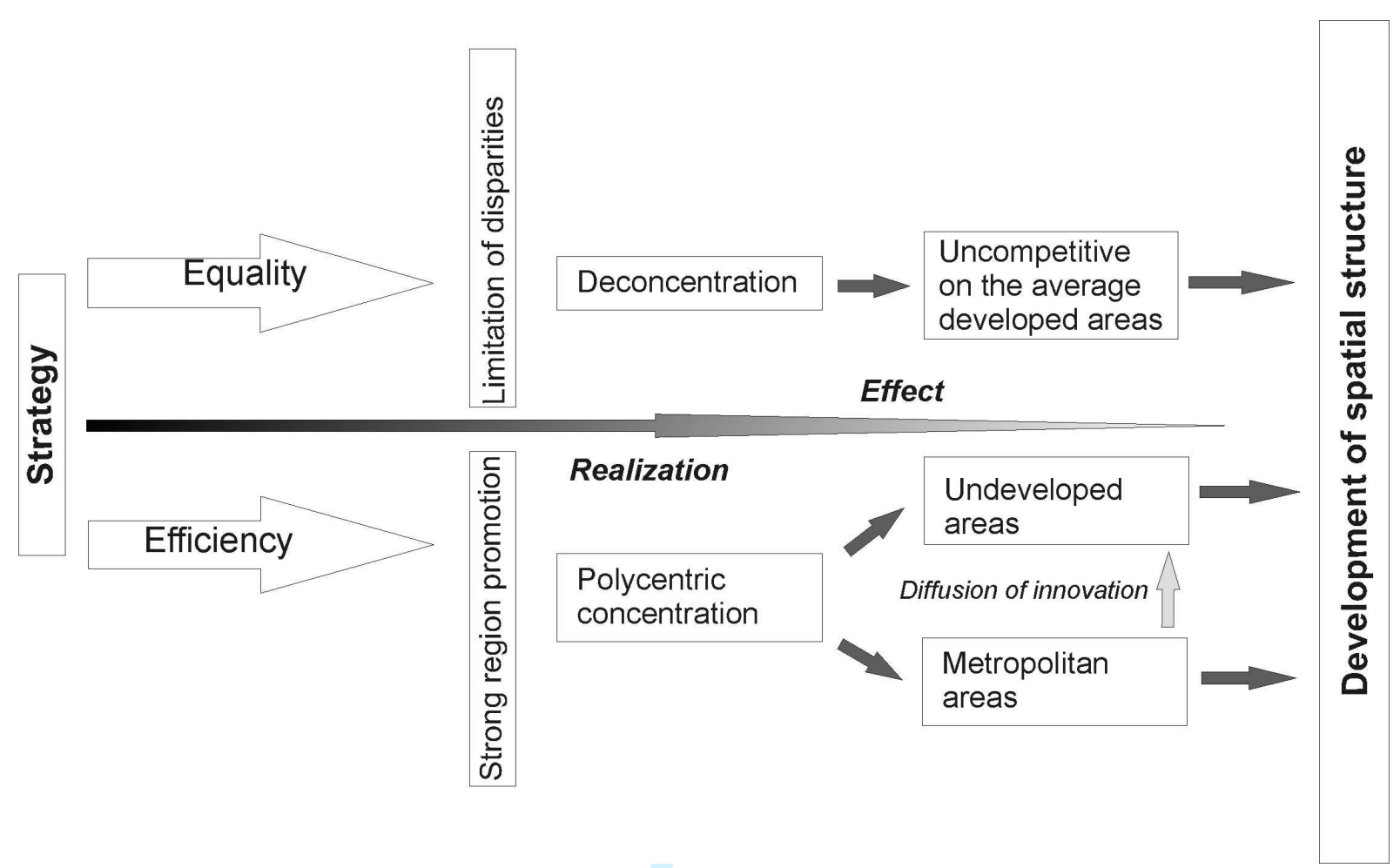

Fig. 1. The major dilemma of the strategy for the spatial management of the country equality or efficiency? 
$2 \mathrm{a}$

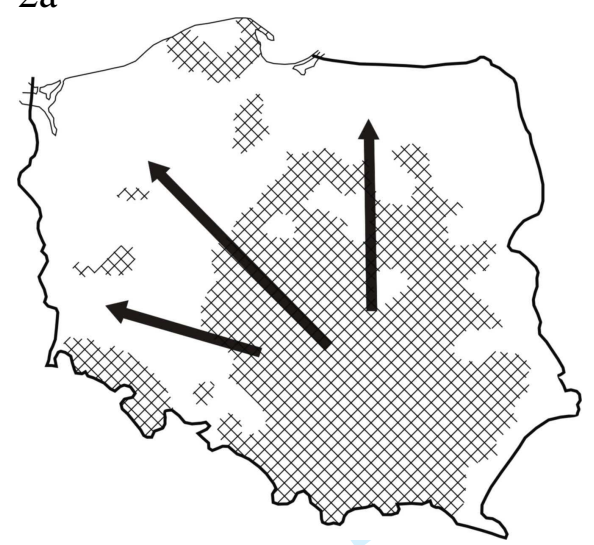

$2 \mathrm{~b}$

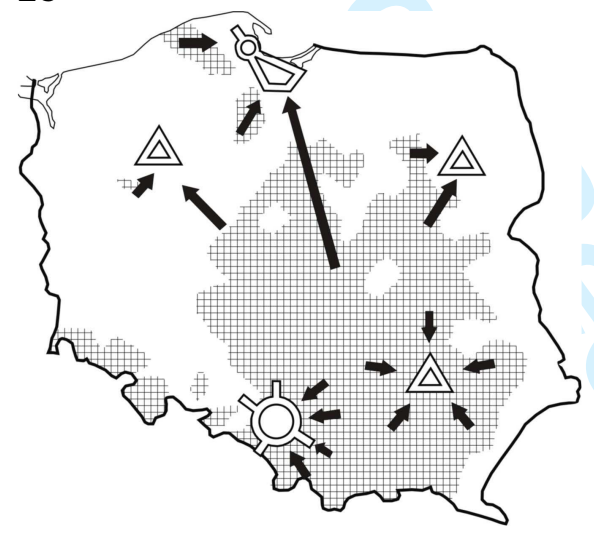

$2 \mathrm{c}$

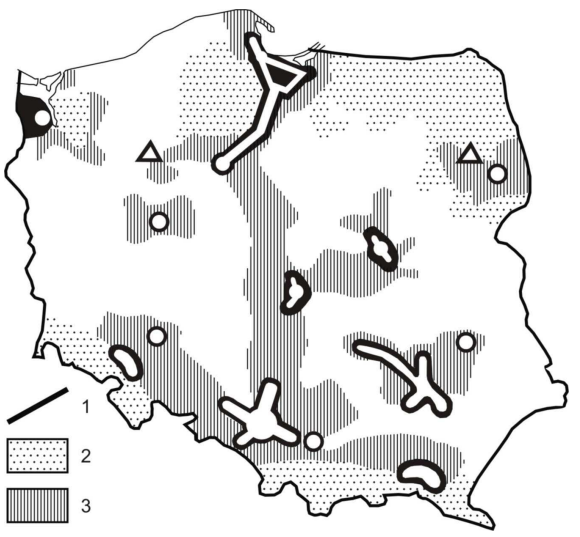

Fig. 2. Programme for development of agriculture in the Study for the National Plan $2 \mathrm{a}$ - period of reconstruction (allocation of the "excess" farming population to areas of land abandoned by the Germans), 2b - period of industrialization (allocation of the "excess" farming population to industrial areas), $2 \mathrm{c}$ - period of urbanization (division of territory into agricultural regions 1 - highest intensification, 2 - animal production, 3 - intensive agriculture)

Source: K. L. Toeplitz (1978) 


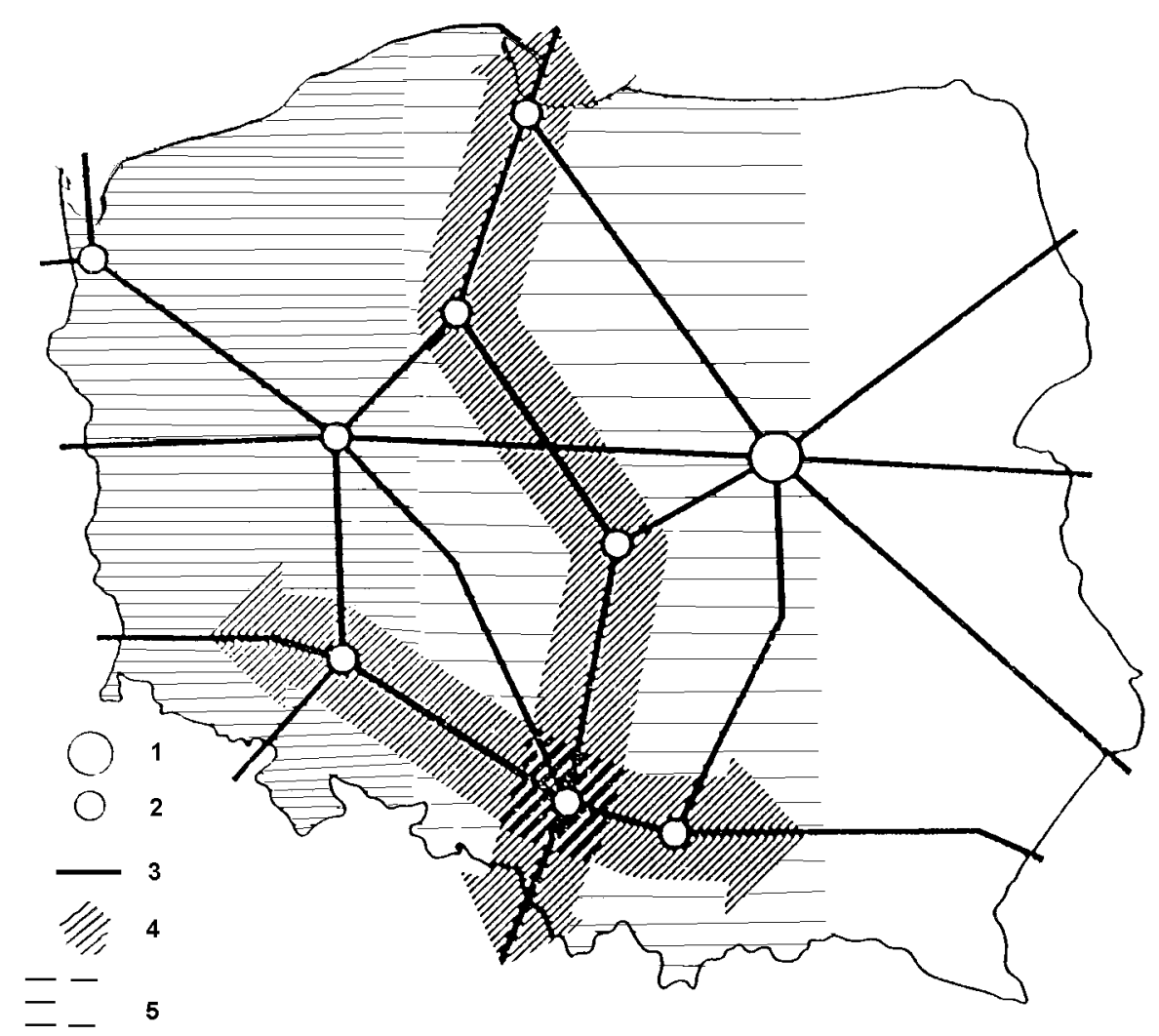

Fig.3. Scheme of the Poland's spatial structure in 1950

1 - the capital city, 2 - the largest urban centers, 3 - a network of main transportation links, 4 - main axes of industrial development, 5 - schematic graph of investment zones

Source: Dziewoński, Malisz (1978, p. 26) 


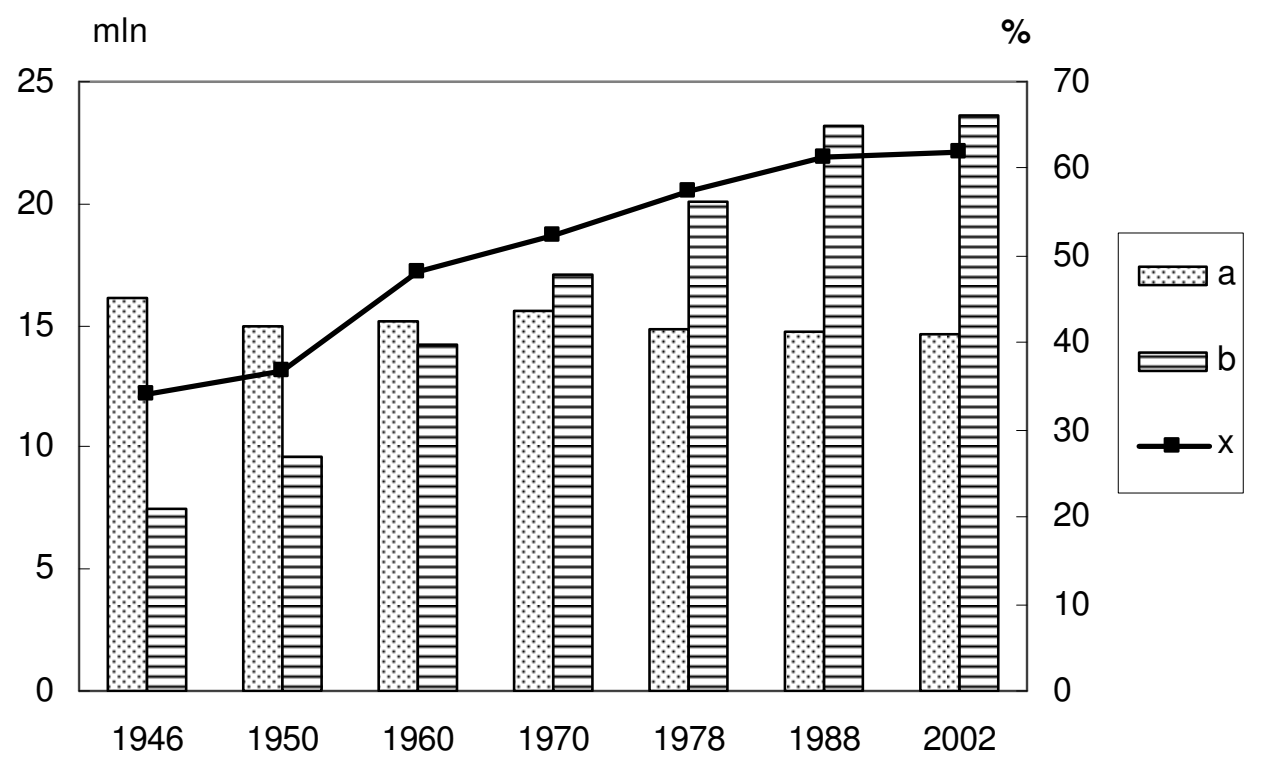

Fig. 4. The change in rural (a) and urban (b) population numbers and the percentage of urban population (x) in the years 1946-2002 (based on National Censuses) 


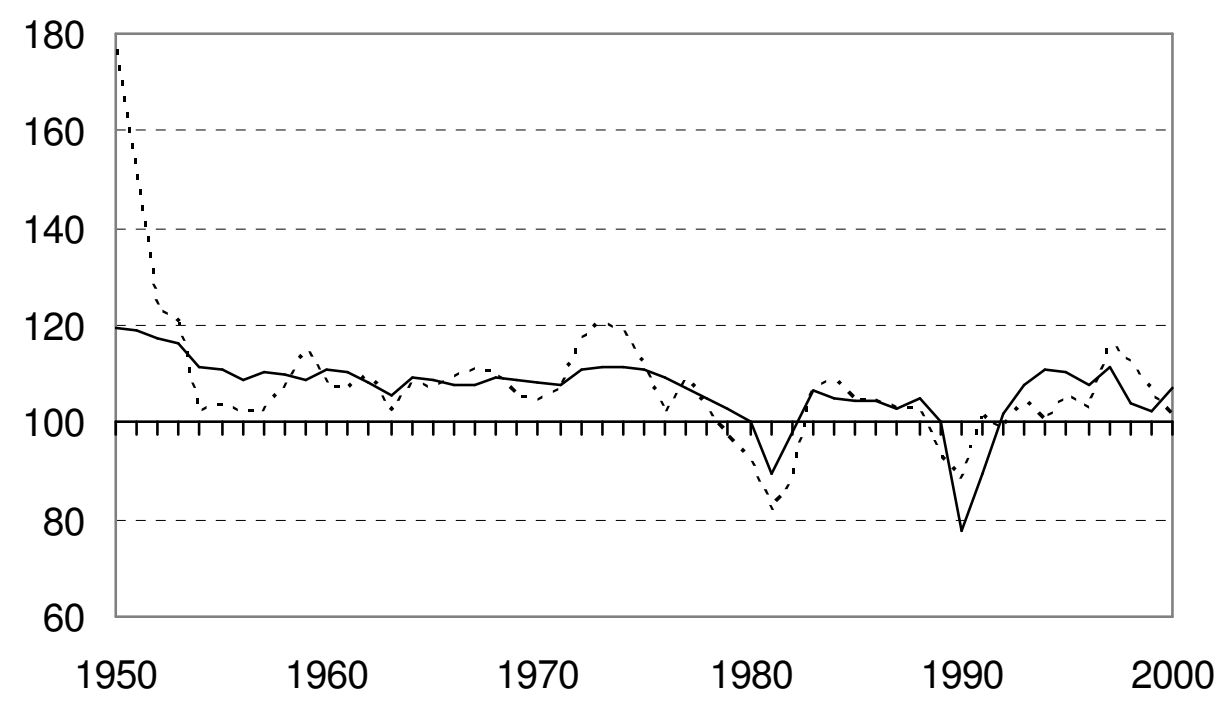

Fig. 5. Indices of gross output of industry and sold production of construction in the years 1950-2000 (current prices) 


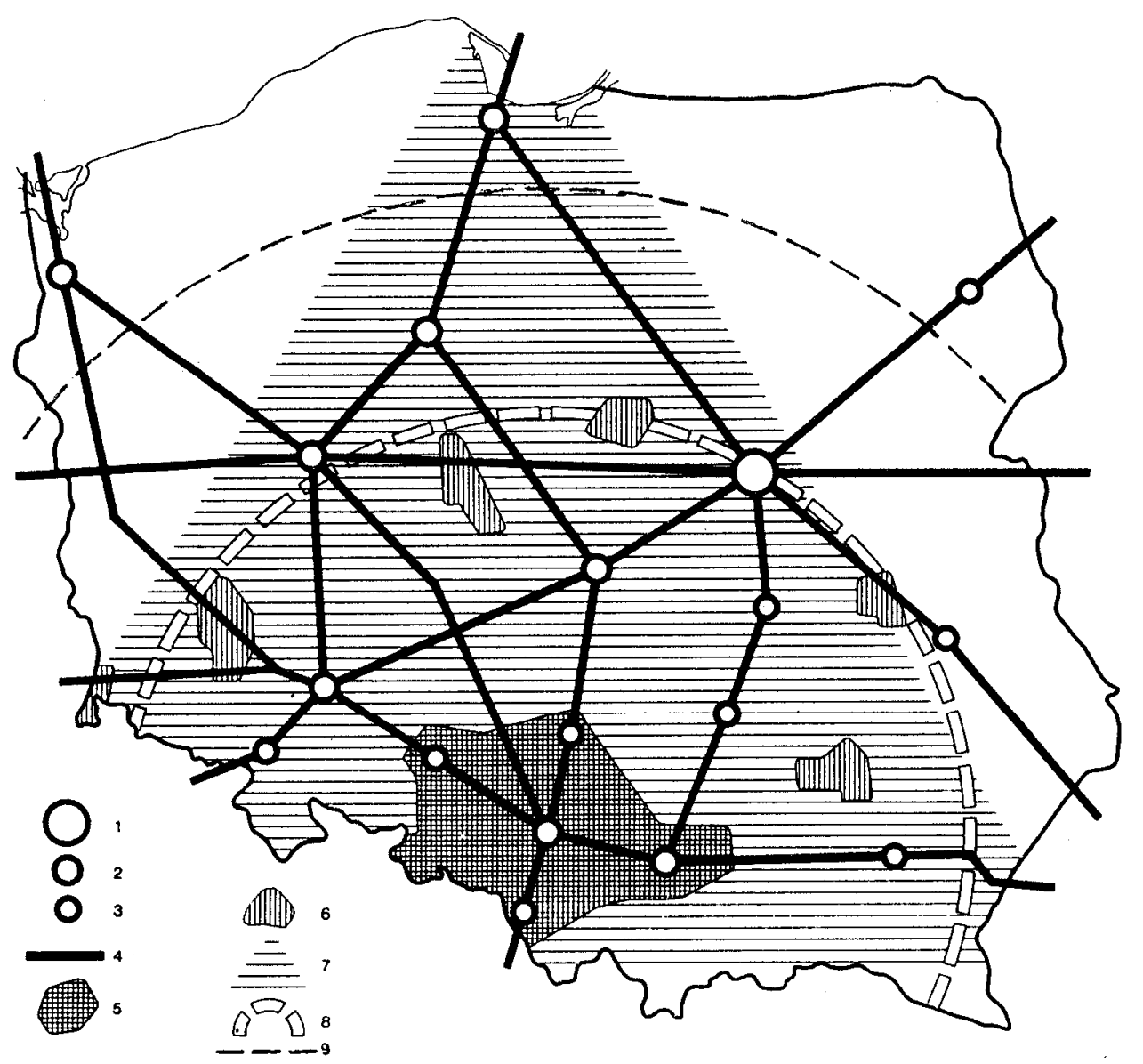

Fig. 6 Scheme of spatial structure of the country in 1970

1 - the capital city, 2 - key urban centers, 3 - medium-sized urban centers , 4 - main transportation links, 5 - southern industrial macro-region, 6 - new industrial districts, 7 - area of the country with higher level of industrialization, 8 - arc with a radius of $300 \mathrm{~km}$ from Katowice, 9 - range of effect of the new industrial districts

Source: Dziewoński, Malisz (1978), p. 32. 


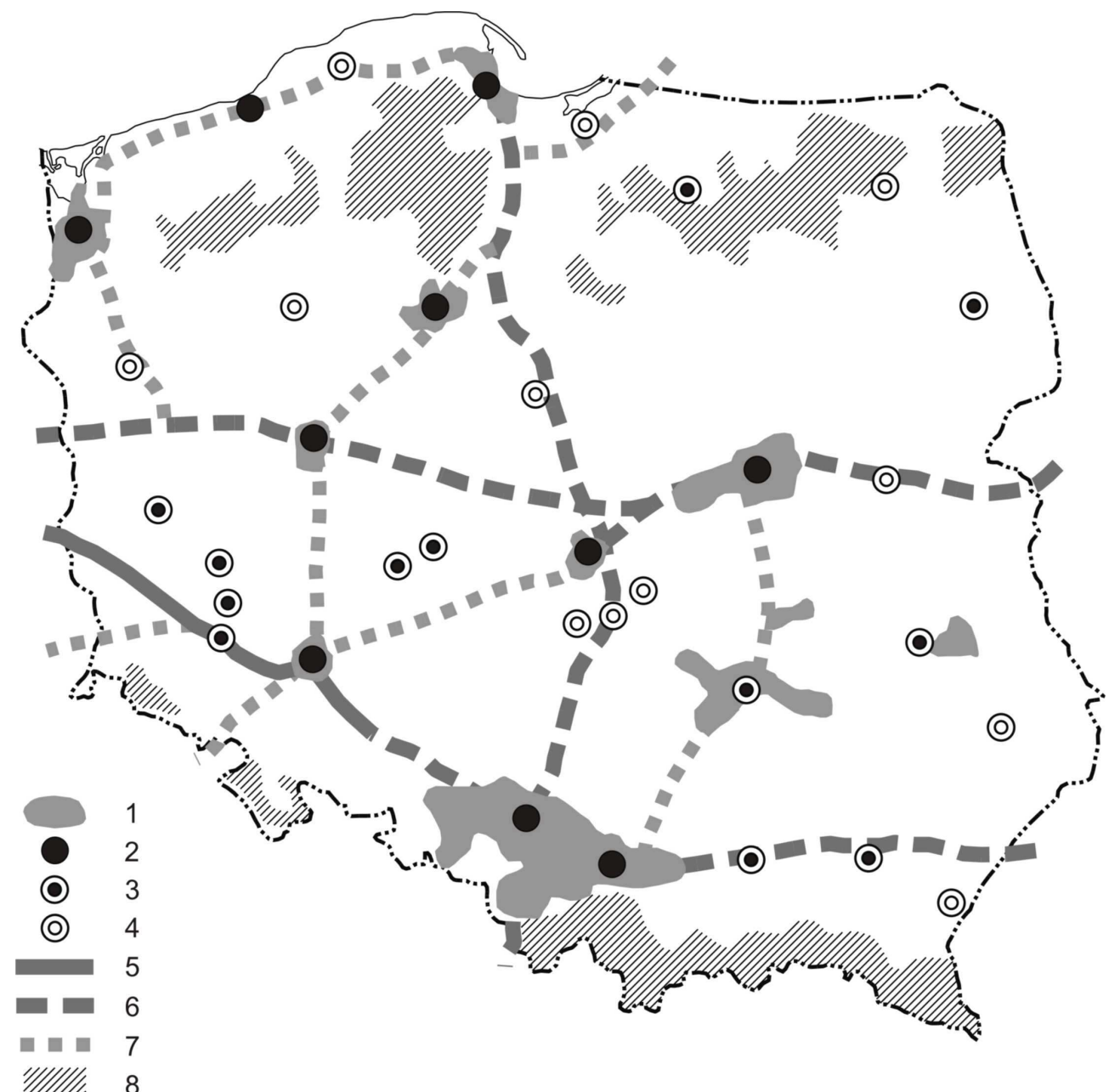

Fig. 7. The selected elements of the Synthesis of the Project of Spatial Organization of the Country up to 1990

1 - urbanized areas, 2 - developed agglomerations, 3 - potential agglomerations, 4 - growth centers, 5 - expressways, 6 - planned expressways up to 1990, 7 - planned expressways after 1990, 8 - areas of major significance for tourism and recreation

Source: author's own study on the basis of the Plan ... 1974) 


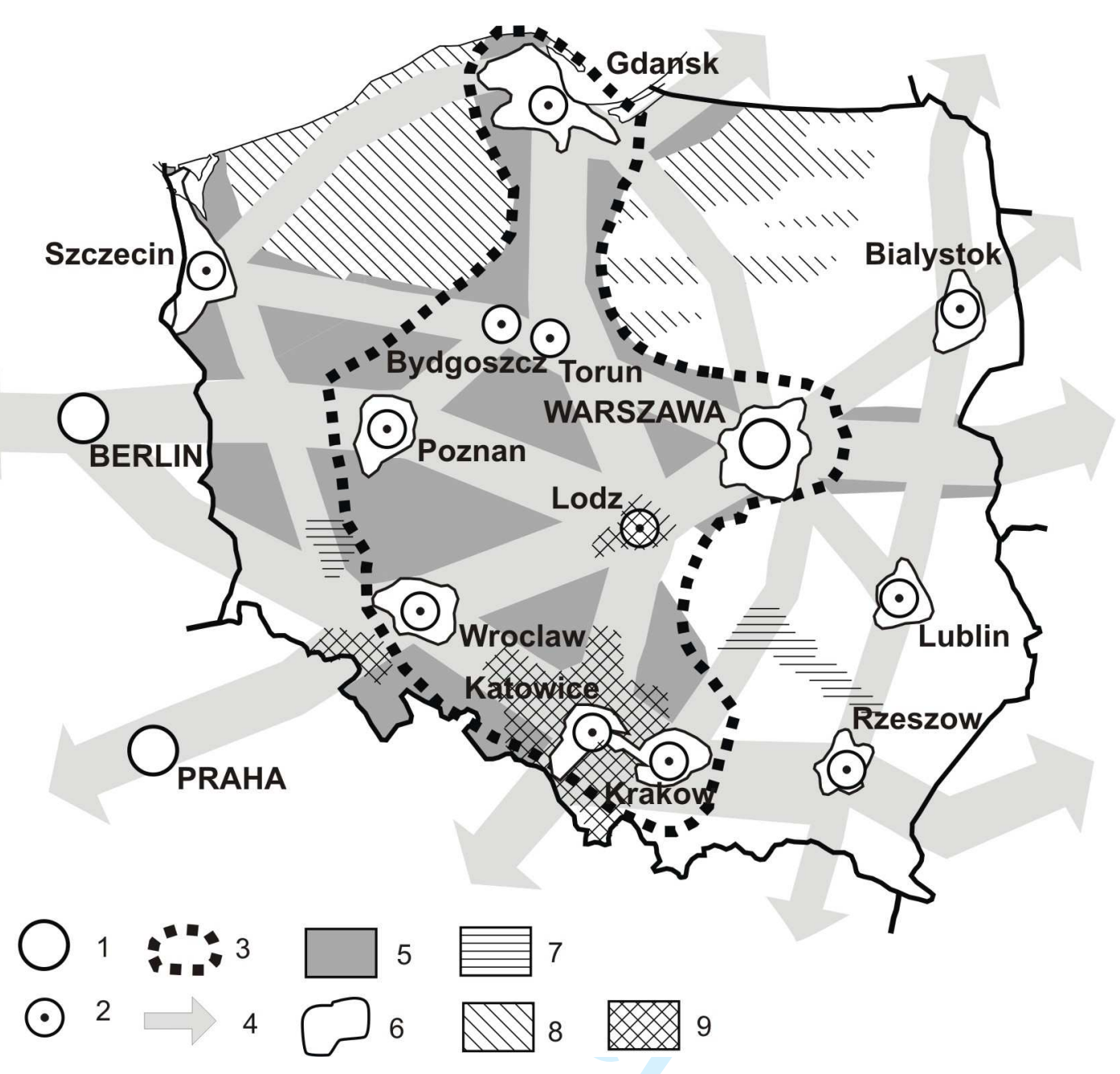

Fig. 8. Concept of the policy of the country's spatial organization. Scheme of a sustained development model

1 - the capital metropolises, 2 - European centers of polarization, - 3 - zone of accelerated economic concentration, 4 - potential belts of accelerated growth, 5 - zone of accelerated development, 6 - zone of sustained metropolization, 7 - zone of overcoming of the economic base crisis, 8 - zone of coming out of recession, 9 - zone of active restructuring Source: study on the basis on National Spatial Arrangement Policy, (2001) p. 534 


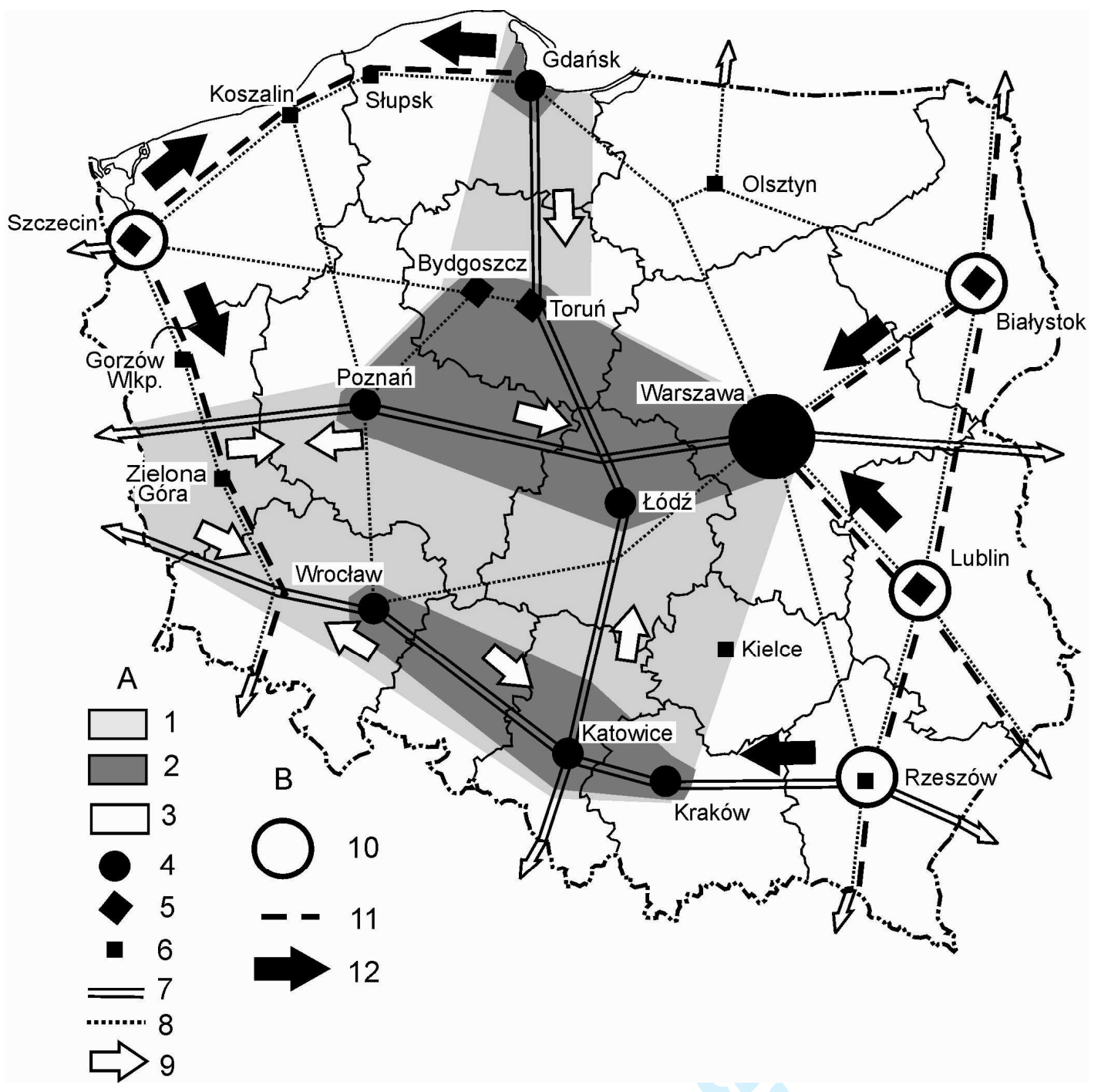

Fig. 9 Scheme of development of spatial structure in Poland

A - outline of spatial structure: 1 - area of above average developmental potential, 2 - area of accelerated growth, 3 - areas of stagnation, 4 - mature agglomerations, 5 - growing agglomerations, 6 - most important regional centers, 7 - existing or planned expressways, 8 other important arterial roads or main lines, 9 - directions of economic links, B - elements stimulating sustainability, 10 - growth stimulating centers, 11 - arterial roads or main lines of top priority, 12 - the proposed directions of links

Source: author's own study 